\title{
7. Phoenix rising 2000 How Timor-Leste's media bloomed from the ashes of violence and bloody conflict
}

\begin{abstract}
Commentary: The second annual Dili Dialogue Forum in July 2018 was sponsored by UNESCO, UNDP and the Timor-Leste Press Council and the governments of New Zealand, Japan and the Netherlands. Delegates came from Asian press councils and media freedom bodies, including the South East Asian Press Alliance, and from Cambodia, China, Hong Kong, Indonesia, Japan, Philippines and Thailand. For the first time, Papua New Guinea's Media Council was represented by its secretary and popular television presenter Belinda Kora. The author reflects on two days of presentations and roundtable discussions at the Forum - which saw Dili becoming the hub for a much bigger alliance of Asia-Pacific press councils - in the context of his long involvement in Timor-Leste media freedom issues.
\end{abstract}

Keywords: Dili Dialogue Forum, journalism education, media councils, media freedom, press councils, Timor-Leste

\section{BOB HOWARTH}

Media consultant

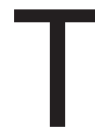

HE FIRST time I flew into Dili on February 25, 2000, to help launch its first independent newspaper, the Timor Post, the airport was burning, like much of Dili. It was a pure accident. I was on a media rescue mission.

The Aussie sitting next to me on the Air North 'puddle jumper' flight that day as we watched the fire remarked casually: 'Situation normal'. And no customs or immigration, only soldiers, UN police and Blackhawk choppers were on the tarmac.

Welcome to the capital of the tiny former Portuguese island colony, a 90-minute hop by air from Darwin on the northern tip of Australia. Australian military forces headed a UN mission to restore peace on the divided island of about 900,000 people after Indonesian-controlled militias went on an orgy of destruction and killing after the Timorese voted overwhelmingly on August 30, 1999, for independence from Indonesian control. Indonesia invaded the country in 1975 with US and Australia's quiet nod after the Portuguese left in a rush after centuries of rule (Jolliffe, 1978). The invaders murdered five Aussie newsmen, the legendary Balibo Five, for which no-one has faced justice (Maniaty, 2009; Morris, 2017). It was later estimated more than 100,000 Timorese died at the hands of their invaders.

110 PACIFIC JOURNALISM REVIEW 24 (2) 2018 
In the rampage of occupying forces, much of Timor's infrastructure was destroyed. Buildings burnt, livestock slaughtered and tossed down wells, and massacres of innocent civilians. All media facilities, printing presses, offices with computers, transport and housing were wrecked before UN peacekeepers brought relative calm to smouldering Dili (Peake, 2013).

In early 2000, as editorial technology manager I was winding down an operation I helped plan to beat the dreaded Y2K bug at Queensland Newspapers (QN) in Brisbane. Remember it? Planes were going to fall out of the sky, computers would crash because they had only two digit dates for the year and we scrapped millions of dollars worth of IT equipment because it couldn't handle four digits... the dreaded year 2000. It turned out to be a fizzer and the world didn't end, nor planes fall out of the sky.

To cut a long story short, I got a call out of the blue (as a disaster recovery 'expert') from the University of Queensland to meet 13 leading Timorese journalists who had flown to Brisbane to attend a special course in 'post-conflict reporting' run by the Reuters Kosovo bureau chief. Basically, it was about how lazy, unprofessional reporting could cause flare-ups and more deaths in conflict areas.

The journalists rated the course excellent but added: They had nothing to go home to. Nada. Not one computer, not one printing press... nothing.

After meeting them I asked my boss, the managing director of QN John Cowley, if I could save the company $\$ 10$ per item we were paying a contractor to take away the non-Y2K equipment. He said go for it. The following day, the Timorese team flew to Darwin on a now-defunct Ansett Airlines jet (half-owned by News Limited) carrying half a tonne of cargo including 12 PCs, seven laptops, two laser proofers and half a pallet of A3 and A4 paper. None of it was Y2Kcompliant ... but who cared which year it was then?

When they landed in Darwin all the equipment was left behind because under UN flight rules passengers on their C130 Hercules shuttle to Dili could only take what they could carry. The gear was left on pallets in the Northern Territory News' paper store, part of the News Limited empire.

Fortunately, I was able to fly to Darwin a couple of weeks later on another News group assignment to train NT News staff on our brand new online NewsText library system. During three days of training I contacted Perkins Barges who were ferrying bulk supplies to Dili for the UN from Darwin. Perkins agreed to carry free-of-charge all the Timor gear and I wrote a nice story for the NT News about how they were helping the first 'free press' newspaper start up.

News HQ in Sydney told me I might as well keep going and fly to Dili to help set up the paper. Mission Impossible loomed. My friends Hugo da Costa (founding editor-in-chief, now an MP), Santina Santos (current director) Rosa Garcia (current editor), Jose Ximenes (current Press Council director) and another 12 dedicated journalists awaited the equipment arrival and yours truly, de 
facto production editor. They were, and still are, proudly the owners, not some foreign media company.

When I got there, the power blacked out every couple of hours: Ayah! Biggest headache, no aircon, no UPS (uninterrupted battery power supply to stop computers crashing) and general mayhem in sauna conditions.

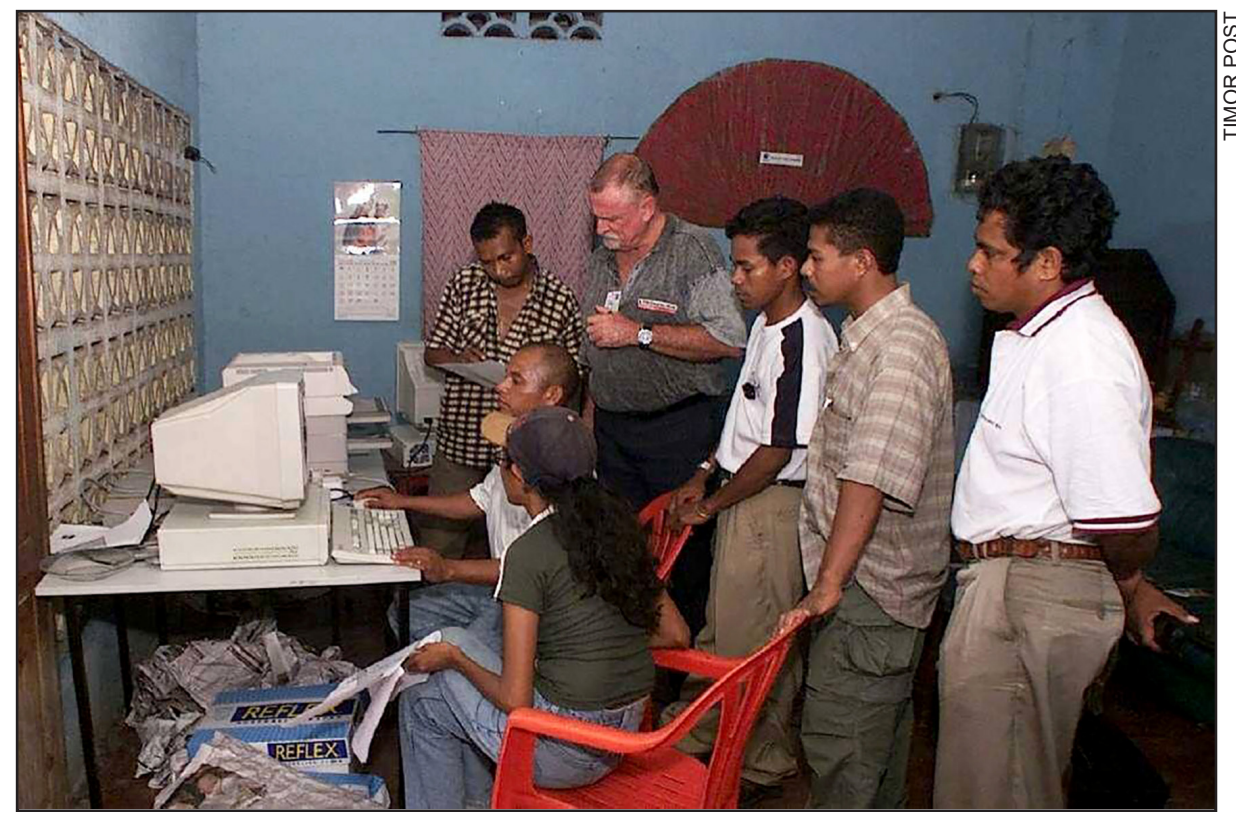

Figure 1: Flashback to the first edition of the Timor Post being produced in sauna conditions in Dili, Timor-Leste, on 28 February 2000. Standing left are founding editor Hugo Da Costa (now an MP) and the author, Australian journalist Bob Howarth.

We solved the power crisis thanks to the Brisbane-based Army support battalion billeted in the government building (still smouldering with destroyed land title records) next to the new Timor Post's designated office and the army had huge generators. So I knocked on the barbed wire, saw the obliging colonel who generously assigned two of his electricians to run cables across a narrow lane to the Timor Post. Beautiful. Lights, action, computers!

We hooked up the computers and used 'sneaker-net' (wearing sneakers carrying floppy disks to transfer copy and pix to the page designer's PC). Deadline was only two days to the launch on Sunday, February 29, when the Indonesian President Gus Dur was due to visit and virtually apologise for the damage his withdrawing army had caused.

Next problem: How do we print with every local machine wrecked or burnt by the outgoing Indonesian forces?

I was staying at a construction-camp-type donga hotel called The Paximus (now the Ventura Hotel) and in the manager's office I spied a gleaming new 
high-speed A3 photocopier. When I told the Canadian manager, Bob Buskins, what we were up to, he agreed we could use the machine as long as we supplied paper and toner. Our target was 10 news pages in Tetum language (a world-first) and another page in English and one in Portuguese, a format the Timor Post still runs with much bigger Tetum pagination.

I bought up all the A3 paper in Dili later that day on my big boss, Rupert Murdoch's, company credit card. Thank you, obrigado, terimah kasi Uncle Rupert (another expenses secret).

\section{Saturday February 28, 2000:}

The Timorese worked all day and night with beautiful nonstop power from the army gensets purring away next door and put the paper to bed working 20 hours straight then high-speed photocopying for another four hours till sunrise to produce 300 copies. The only hiccup was earlier when a large pig (Dili still has the odd loose pig, goat, chicken roaming back streets) waddled through open doors into the sweltering newsroom and I objected. They agreed. No pigs in the newsroom.

Then next morning as huge crowds gathered for the Indonesian President's arrival (highly-controversial at the time with unfounded rumours of assassination plots) our happy, bleary-eyed team drove around Dili's pot-holed streets in battered yellow taxis flinging out free copies of the Timor Post. I was interviewed later that day on $\mathrm{ABC}$ radio in Australia. I said I wished I could see one day

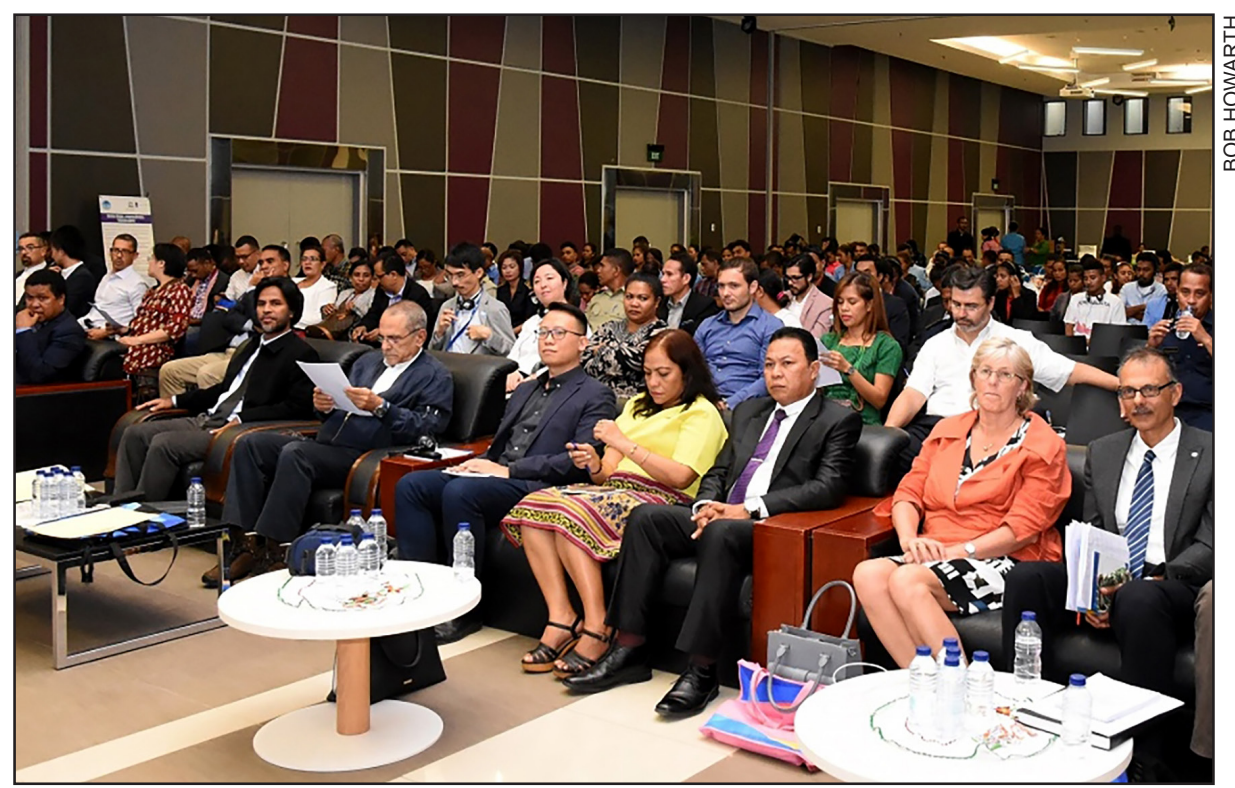

Figure 2: Pix: The audience at the Dili Dialogue Forum with former President and Nobel Peace Prize winner Dr Jose Ramos-Horta in the centre front row. 
people literally fighting over the Courier-Mail newspaper back in Brisbane. The Timor Post continues proudly today in the same building with its own colour press and circulates all over the country. Viva Timor-Leste! Viva Timor Post!

\section{Fast forward to July 15 2018:}

I fly back to Dili from Darwin on an Air North Embraer jet and arrive at a modern small terminal where customs and immigration is fast and pay a US\$30 visa fee for one month. Dili has the cheapest duty-free in the Asia/Pacific, usually half the price of goods in Darwin.

And Dili is booming. Four days later I join 400 people in the US $\$ 8$ million conference centre in the gleaming high-rise Ministry of Finance, one of several new landmarks on this city of 200,000 plus. The occasion is the second annual Dili Dialogue Forum. It is sponsored by Unesco, UNDP and the Timor-Leste Press Council, New Zealand, Japan and the Netherlands. Delegates fly in from Asian press councils including the South East Asian Press Alliance, Indonesia, Thailand, Cambodia, Philippines, Japan, China and Hong Kong. For the first time, Papua New Guinea's Media Council is represented by its secretary and popular TV presenter Belinda Kora.

During two days of presentations and round-table discussion the Forum agrees Dili will become the hub for a much bigger alliance of Asia/Pacific press councils, media freedom strength in unity.

Speakers include senior representatives from Unesco, Timor-Leste's Minister for Communications, the International Federation of Journalists' barrister Jim Nolan and the various country media councils who all report on threats to their national press freedom. Several speakers highlight the fact that Timor-Leste has the highest World Press Freedom ranking in Asia-95th in Reporters Sans Frontières' annual World Press Freedom Index (RSF, 2018).

So how did this happen?

From early 2000 with the launch of the Timor Post and the revival of an existing daily, Suara Timor-Leste, the media scene in Dili bloomed as aid money poured into the latest emerging independent country. Major donors like USAID, AUSAID, JIKA (Japan), the EU and even Australian journalists all helped with cash, kind and training. In my case I flew to Dili on several occasions to help with training at the Timor Post and later the Jornal Independente daily. As of August 2018 all these dailies continue publishing plus the daily Diario.

However, some NGOs and foreign donors started questioning whether a country of 1.5 million people could support four daily newspapers with radio the most popular media across the country and local TV plus a vast range of neighbouring Indonesia's TV stations easily accessible. All print media were struggling with advertising revenue dropping heavily as their Parliament met in crisis to establish a stable government and pass much delayed budget legislation. 
The country meanwhile had its two-year old Press Council (Conselho De Imprensa) set up with government funding plus assistance from UNDP for professional training. The TLPC impressed delegates to the Dili Dialogue Forum with its statistics. The council has 38 staff including a five-man board, 38 staff covering media monitoring, dispute resolution, training and admin plus transport including two drivers (who multi-tasked on data input and as photographers). The hardware included nine vehicles, 21 motorbikes and a network of 50 computers for admin and training plus their own IT specialist.

The TLPC's latest projects include lobbying Google Translate and Facebook to include one of its two official languages Tetum. Portuguese (on Google Translate) is also an official language but it is not taught in local schools until high school level. The Timorese know that a viable online media will need Tetum Translate as an option. After centuries under colonial rule Timorese children did not have any schooling until 1940. Only Portuguese citizens' children were allowed to attend a handful of schools. Later they were taught in Bahasa Indonesia during the 25 years of occupation until 1999.

Investigations continued at the time of writing into setting up a Timorese Fact Check authority combining resources of the TLPC and the University of TimorLeste, similar to the Fact Check partnership in Australia between the ABC and Melbourne's Monash University.

The President of the TLPC, veteran newsman Virgilio da Silva Guterres (Gil) told the Dialogue Forum that when the council was set up he and fellow director and lawyer Paulo Arujio were appointed by Parliament and other directors elected by journalists. However, he said their aim was for the President and legal advisor director to be directly elected by the journalist membership. Gil Guterres said the TLPC was not regulated by the government of the day and stressed the importance of media self-regulation without government influence.

Nobel Peace Prize winner and former President Dr Jose Ramos-Horta spoke on the disturbing of low levels of press freedom in many countries. He said he had never seen such hostility to mainstream media as in the United States under President Trump. A strong, professional, independent media was essential in any country to fight for good government.

Dr Horta told delegates his country had its only truly fair election in 2002 when no-one had any money. He said now Timor-Leste had learned the lessons from Indonesia, Thailand and the Philippines of 'money democracy'.

His advice to journalists investigating corruption was 'do not rush... take your time'. Reporters covering corruption should be as careful as a prosecutorgeneral, he added.

Dr Horta addressed the issue of dwindling revenues for print media in Timor-Leste. He suggested subsidies for newspapers to encourage the nation to develop better reading habits and other assistance such as lower power bills and 
cheaper newsprint and ink.

In the week following the Dili Dialogue, 25 journalism students and junior reporters completed five months of professional training organised by the TLPC and funded by the UNDP. The chief organiser UNDP's Yuichi Ishida introduced the concept of data gathering and inclusion of graphics and bar charts as well as video editing and news photography. The training finished at a students' retreat at the five-storey landmark Timor Plaza complex to discuss future professional training such as layout and design and writing for online publication.

Plans for the 2019 Dili Dialogue Forum on May 9-10 have already drawn expressions of interest from Pacific press councils in Australia, New Zealand, Solomon Islands, Samoa, Tonga and Fiji. As a result, the 2019 forum is shaping up to become a very real alliance between Asia and the Pacific media councils.

\section{References}

Jolliffe, J. (1978). East Timor: Nationalism and colonialism. St Lucia, QLD: University of Queensland Press.

Jolliffe, J. (2010). Balibo [2nd Edition]. Brunswick, VIC: Scribe Publications.

Maniaty, T. (2009). Shooting Balibo: Blood and memory in East Timor. Sydney, NSW: Penguin/Viking.

Morris, L. (2017, October 16). Remembering Australia's Balibo Five. National Geographic. Retrieved from www.nationalgeographic.com.au/australia/rememberingthe-balibo-five.aspx

Peake, G. (2013). Beloved land: Stories, struggles and secrets from Timor-Leste. Brunswick, VIC: Scribe Publications.

RSF (Reporters Sans Frontières/Reporters Without Borders) (2018). 2018 World Press Freedom Index. Retrieved from https://rsf.org/en/ranking

Bob Howarth is an Australian media consultant with more than 50 years of industry and training experience in the Asia-Pacific region, including being managing director in Papua New Guinea for News Corporation Australia. He has worked in Australia, Fiji, Indonesia and Timor-Leste as well as Papua New Guinea, and has been responsible for initiating and developing digital security systems for news media. Howarth has been part of international academic journalism programmes such as at Bond University, Queensland, and is a correspondent for the Paris-based global media freedom watchdog Reporters Without Borders. bhowarth@onthenet.com.au 